An Evaluation on the Change of the Basic Principles of Turkish National Education in the Context of Sociopolitical Paradigms

Turkish Online Journal of Qualitative Inquiry (TOJQI)

Volume 12, Issue 2, April 2021: 249-272

DOI: $10.17569 /$ tojqi.841896

Research Article

\title{
An Evaluation on the Change of the Basic Principles of Turkish National Education in the Context of Sociopolitical Paradigms ${ }^{1}$
}

\author{
Turan Akman Erkılıç²
}

\begin{abstract}
Various variables in social, economic and political dimensions affect the administration of education systems of countries. Turkish education system is fundamentally based on the principles manifested in the Basic Law of National Education. In Turkey, education has always been under the influence of such social and political movements as socialist, liberal, social-democratic groups and Kemalism, conservative and political Islamic groups and Turkish nationalism. The main purpose of this study is to reveal how and under which principles of the basic principles of national education have changed in the historical developmental process. The study is a document review type of research. Thematic analysis was used combined with interpretivist approach in the process of analyzing and interpreting data obtained from the document review. As a result, these findings have been reached: The change in the basic principles generally happens during the social, economic and political turbulent periods of the country. The academic and scientific view on educational problems remains weak compared to the philosophical, political and belief-based views. The principles have been interpreted based on philosophical, belief, ethnic and political views increasing in Turkish society. It is recommended to investigate the basic principles and the researches and the articles which have been written on basic principles from different perspectives at historical, social, economic and politic dimensions. Also, it is recommended to compare the basic laws and principles of education in other countries to Turkish equivalents.
\end{abstract}

Keywords: Education system, ideologies, paradigms, basic principles, change.

\footnotetext{
${ }^{1}$ Ethical committee permission is not required in this research since the data were gathered through document analysis.

2 Assoc.Prof.Dr., Anadolu University, Faculty of Education, Department of Educational Sciences, terkilic@anadolu.edu.tr, ORCID ID: 0000-0002-2507-2663.
}

Received: 16.12.2020, Accepted: 12.02.2021 


\section{Sosyopolitik Paradigmalar Bağlamında}

\section{Türk Milli Eğitimin Temel İlkelerinin Değişimi Üzerine Bir Değerlendirme}

Öz

Sosyal, ekonomik ve politik boyutlu değişkenler, ülkelerin eğitim sistemlerinin yönetimini etkilerler. Türk eğitim sistemi, Milli Eğitim Temel Kanununda belirtilen ilkelere dayanmaktadır. Türkiye'de eğitim; sosyalist, liberal, sosyal demokrat, Kemalism, muhafazakâr ve siyasal İslamcı gruplar ile Türk milliyetçiliği gibi akımların etkisi altındadır. Araştırmanın temel amacı, tarihsel gelişim süreci içerisinde Milli Eğitimin temel ilkelerinden hangilerinin nasıl değişim gösterdiğini belirlemektir. Çalışma, doküman analizi türünde bir araştırmadır. Doküman analizi ile toplanan verilerin analizi ve yorumlanması sürecinde yorumsamacı yaklaşımla birlikte tema analizi kullanılmıştır. Sonuç olarak şu bulgulara erişilmiştir: Temel ilkelerde değişikler genel olarak ülkenin sosyal, ekonomik ve politik çatışma dönemlerinde gerçekleşmiştir. Eğitim sorunları üzerine akademik ve bilimsel görüşler; felsefi, politik ve inanç odaklı görüşlerle karşılaştırıldığında alanda daha az yer almaktadırlar. İlkeler, Türk toplumunda daha çok yükselen felsefi, inanç, etnik ve politik odaklı görüşlere göre yorumlanmaktadır. Temel ilkeler ve ilkelerle ilgili yapılmış araştırma ve makalelerin tarihsel, sosyal, ekonomik ve politik açılardan araştırılması önerilmektedir. Ayrıca temel kanun ve ilkelerin diğer ülkelerdeki temel kanun ve ilkelerle karşılaştırılması da bir başka öneri olarak önerilmiştir.

Anahtar Sözcükler: Eğitim sistemi, ideolojiler, paradigmalar, temel ilkeler, değişim. 


\section{Introduction}

Various variables in social, economic and political dimensions affect the administration of education systems of countries. Legal regulations constitute a part of social, economic and political factors. Written legal arrangements are strong administrative texts in that they are both written and supported by state authority through tangible sanctions (Akıntürk, 2008). The Turkish education system is also supported by various types of legal texts such as the Constitution, legislation, decree law (DL), Presidential decrees (PD), regulations, and statutes.

It is possible to list the written legal sources affecting the Turkish education system in different ways in terms of their importance and effects. However, the Turkish National Education Basic Law No. 1739 has a different importance. As stated in its name, the law numbered 1739 forms the basis of the Turkish education system in a sense and is regarded as the constitution of the system. The basic principles of Turkish national education in the Basic Law are of the essence in terms of determining what qualifications the education system will have and how it will be managed both on the basis of general content and principles. It is an important topic of discussion and study on what changes have been made since 1973, when the basic law came into force in these principles, and what processes and factors affected the aforesaid changes in terms of social, economic and political aspects.

In general, the education system itself implies the intellectual perspective and raising the certain type individuals. In fact, in Turkey various political currents such as socialism, liberalism, political Islamism, social democracy, conservatism, progressiveness and Kemalism have different opinions on the education system and its practices. According to some opinions, the system has constantly been under the influence of anti-secularist movements and relative secular gains have been lost (İnal, 2008; Aybek, 2015). In another aspect, the system has an imperious, political tutelage and totalitarian essence; It needs liberalization and normalization. It is emphasized that the New Turkey needs an educational mentality which is open to competition and civilian trends; and enables new ideas to be included in education (Başdemir, 2015). In a sense, the essence of many issues discussed 
such as equality of opinions-chances, democracy, secularism, Ataturk's principles and coeducation are found in the basic law and they should be discussed and addressed.

Considering Education in Turkey based on social, economic and political terms, present approaches can be grouped into five main sub-titles. They are socialist and micro nationalist movements, liberal views, social democrat and Kemalist thought groups, conservative and political Islamist groups and Turkish nationalist views. These different views have direct or indirect oppositions, supports, positive and negative opinions about the basic principles expressed in the Basic Law (BL).

Considering socialist movements, the following views come to the fore: According to socialists, politics is a product of the class struggle and education functions to convey the ideology of the existing economic system (Macionis, 2013). Socialists' opinions on the education in Turkey are interpreted in this perspective. Socialists clpurpose that the secularism in Turkey is not of universal nature, the compulsory religion classes are not democratic and tend to assimilate different faith groups. The governments shape education with a "reactionary" approach according to their own ideologies (Gezgin, 2017). In addition, education in the mother tongue is a necessity in terms of democracy and pedagogy according to some trends in this group (Çiftyürek, 2006). The educational guidance and placement function found in the laws is insufficient due to the fact that education is an institutional superstructure (Tezcan, 1993). Although they may be examined separately from the Socialists movements, opinions of some Kurdish nationalists on the education can be summarized as follows: According to this groups, the Kurdish problem is the leading among the dynamics which will give acceleration to Turkey democratization movement; One of the most important indicators is that "education in the mother tongue" is demanded (Ekinci, 2014; Kizllok, 2013). It is observed that these groups emphasize such issues as equality, justice, education in the mother tongue and equality of opinions-chances.

Liberalism is defined as an ideology which purposes the freedom of thought and belief and the free market economy. Liberal movements in Turkey view the education system in Turkey as status quo and political tutelage supporter in general. These trends, which criticize the Republican era, do not consider Kemalism as an initiative whose purpose is "democracy" and "pluralism" (Hanioğlu, 2017). A significant majority of the liberals are of the opinion that the 
new republic is not a libertarian and democratic model. There are also criticism at the reforms with the argument that a person who embrace liberal view cannot have a centralist and planner view; cannot adopt a policy which purposes to design and perform social engineering (İlkaya, 2014). Liberals have a more marketist, libertarian view which seeks that state is "blind" and at equal distance to all classes and social strata. This approach is viewed as originally "dogmatic" liberalism and tends to join conservative line in Turkey example.

The social democratic worldview is originally a Marxist socioeconomic and political view. Social democracy is defined as the political ideology that purposes to reduce the inequality and injustices which are created by capitalism to an acceptable level in the democratic system (Sarica, 2017). However, it is partly intertwined with Kemalist vision in Turkey. The opinions of the social democrats in Turkey show many similarities with the views of groups which are generally defined as the Kemalists "left." Therefore, in Turkey, the views of social democrats about education show parallelism with those of Kemalists. Social democrats highlight the role of education for equality, justice, the rule of law productive; and social balancing functions for modern society (Aybek, 2015). It can be suggested that the Social Democrat view in Turkey is partly intertwined with "left Kemalism" and partly turns to the original social democratic principles which are "independent" from Kemalism.

Kemalism, as widely accepted, is an example of the struggle to reach modern civilization in Anatolia. Kemalism is the establishment of an independent Republic from an Islamic country which was not able to make the industrial revolution; was semi-colonized and under occupation; with an anti-imperialist approach against the West (Kongar, 2016). Kemalism was inspired from liberalism with the principles of nationalism, republicanism and secularism; and by socialism with the principles of statism, populism and revolutionism (Kışlal1, 2010). According to the Kemalist understanding of education, it should be rational, scientific, work-based, secular and purpose to raise producers (Tezcan, 2011). Aytaç (2001) adds the principles of national unity, eradication of ignorance and discipline to the aforesaid. Kemalism is in a sense a revolutionary quality that destroys the old and establishes the new with the alphabet, language, history and cultural revolutions and (Akyüz, 2010). In summary, the Kemalist education system aimed to raise people with a rational, scientific and secular understanding based on the positivist philosophy. However, it is the kind of secularism which aimed to solve the problem of secularism by combining religion and state affairs rather than 
separating them (Baloğlu, 1990). It can be discussed that Atatürk's education notion displays prennialist, reconstructive, progressive and polytechnicist characteristics in terms of the elements of the education program (Toprakç1, 2011). It is possible to say that the Kemalist line sometimes has tides between the center-right and sometimes center-left, and it has the quality which unites a large citizen community with a common denominator.

Conservatism is based on an understanding that adopts a social solidarity way of life together with protectionist, traditionalist, marketist economic structure. Some of the principles of conservatism are the cautious limitation of power and human passion; private property, prudent life, and the continuation of a moral order (Kirk, 1993). In Turkey, it appears as a political organization preference which aims at protecting social and economic structures; and traditions by putting religious elements. Conservatives oppose the new model created by the republic based on their economic, social and life styles. The opposition to the current principle of secularism aims to change the system thoroughly in the context of creating religious generation models. Some examples of conservative demands in Turkey may be given as applications for strengthening the family, advocacy of tradition, working for the protection of historical texture in cities, placing an emphasis on religious education in educational institutions and the efforts towards the development of Turkish-Islamic culture (Özçelik, 2016). However, conservatism experiences the problems with secularization of society as the welfare level increases (Edge, 2015). Conservative views in Turkey example are observed at the center-right political parties in practice. In addition to this, it can be stated that conservatism has taken a new vision and mission in Turkey starting from the second half of 1990s. New conservatism is regarded as a political view that does not reject innovation, advocates a modest change without fundamentalism, protects historical heritage and tradition, supports the free market economy rather than the statist economy model, advocates individual rights but opposes unlimited freedoms and defends family life. (Özçelik, 2016). It is increasingly expressed that this movement is becoming more radical and is against the secularism and modernization which were achieved with the Republic of 1923. It is also voiced as another reality that this movement has built a conservative education which focuses on religion.

Nationalism may imply many different views such as being a nation or defending a certain self-based on a race / tribe. Different meanings were attributed to nationalism before and after 
the French Revolution; before and after the first and second world wars (Kışlal1, 2016). Nationalism is a social and political organization which is based on the organization of human groups as large, centrally educated, culturally homogeneous units (Batur, 2016). Undoubtedly, it is impossible to place nationalist socialist views on a single ideological pattern. However, in today's Turkey, nationalist socialist movement aims to raise generations who are loyal to customs and traditions and formed by Turkish-Islamic synthesis. Within this context, it can be discussed that the conservatism is dominant in the policies of nationalist socialist approach regarding secularism, democracy and economy. The views of this movement on education exhibit traditionalist, essentialist and structure-protecting qualities.

The importance of the study can be expressed as follows. First of all, studies on the subject matter is quite limited. One of the rare studies on the subject matter is the study named "Evaluation of General Objectives and Basic Principles of the Turkish National Education System" performed by İçer (1997). Apart from this study, the studies performed by Erdogan, 2017; Açıkgöz, 2015; Başdemir, 2015; Çeltikçi, 2014; Coşkun, 2012; Bee, 2008; Çiftyürek, 2006 are the ones which were published in the publications and reports of different philosophical and political paradigm-focused newspapers, general culture-based unions, associations and similar institutions. With this study, it is aimed to add a scientific dimension to the discussions on the basic principles of national education. The study is expected to be able to present an academic perspective to the basic principles rather than a "biased ideological" political perspective. In this regard, the legal dimension, which is one of the basic foundations of education, will be able to be discussed with an academic vision.

Considering all of the aforesaid considerations and reasons, the general purpose of the study is to reveal and evaluate how and based on which criteria the basic principles of national education have changed within the scope of historical development. In line with this general purpose, answers to the following questions are sought.

1) Which principles were included and how were they distributed when the basic principles of national education became effective?

2) How have the basic principles of national education changed?

3) How is the change in question evaluated in terms of social, economic and political aspects? 


\section{Methodology}

The study is a document review. Document reviews study concepts, events and opinions by analyzing documents and records. It is important that the information obtained in the document review is able to reflect the context (McMillan, 2004). The study consists of textbooks, researches, documents, reports, newspapers and similar items in terms of data sources (Ekiz,2009). The documents of the study consist of scientific articles and books on the Turkish National Education Basic Law. In the process of analyzing and interpreting the data resulting from the document review, thematic analysis was used with an interpretive approach (Glesne, 2012). Accordingly, the following thematic analysis steps of Braun and Clark (2006) are used:

1. Familiarization with qualitative data

2. The First coding

3. Searching for themes

4. Reviewing themes

5. Defining and naming themes

6. Reporting

Following the steps of Braun and Clark, at first, the documents subject to the analysis were accessed both in print and on the internet. The original sources of the documents and the ones which were accessed on the internet were examined by three educational science experts; it was observed that there was no difference; and then comparative and repeated readings were performed in order to become familiar with the data. As a result of the first and second codings, it was revealed that the changes were made in 1983, 1997 and 2009, the years mentioned in the formation of the first level themes, and the principles affected by the changes in the creation of second level themes, respectively, were grounded on. While coding, sentence paragraphs, in other words, the items in which principles are expressed, were chosen as the unit of analysis. The findings obtained from the data which were analyzed in line with the interpretive paradigm were also reported in the same paradigm. 


\section{Findings}

The first sub-aim of the research is formed as "What principles were included when the basic principles of national education became effective and how was the distribution of these principles?" Considering the basic principles of national education in the context of text, it can be observed that fourteen articles were included as it was first adopted in the National Education Basic Law on 14 June 1973 (Official Gazette, 1973, pp. 1-2). When the principles in the basic law are reviewed within the context of the general content, the following views can be expressed for the themes: it can be claimed that the sociological protective function is achieved via the principles of Atatürk's Revolutions and Turkish Nationalism (article 10), democracy education (article 11) and the cooperation between the school and the family (article 17). On the other hand, the principles of generality and equality (item 4), the right to education (item 7), equality of opportunity and opportunity (item 8), continuity (item 9), secularism (item 12), and scientific (item 13) can be interpreted as a positivist and democratic.

In the context of the content of the article on democracy education, the relevant principle is highly criticized because of the "prohibition of indoctrinization contrary to Turkish nationalism, which is expressed in the Constitution". As a matter of fact, this understanding is expressed by Açikgöz (2015) as follows: "When we look at the content of the law and its applications briefly, it will be seen immediately that Atatürk nationalism is taken as the basis, that Turkishness and national values constitute the general framework, and that strained national" definitions are preferred instead of universal definitions of secularism and science." The founding will defend this situation as a necessity for the indivisible integrity and protection of the country and the state, while the opposing views argue that it contradicts with "freedom of thought" which is one of the fundamental principles of democracy. As stated by Akin and Arslan (2014), this can be evaluated as a reflection of the influence of the dominant ideology depending on the social, economic and political structure in determining the purpose and content in education.

The effect of the social, economic and political situation of the period cannot be denied in determining the law and basic principles. The aforesaid period was the time in which the discussions on democracy, economic model and political system are concentrated. 
Democracy experience in the country was weak and economy and politics centered "passive" conflicts among different social groups and youth movements were on the agenda. Those were the days when political lines such as secularism, socialism, nationalism and communism were discussed and social turmoil occurred (Öztürk, 2016). Important demographic changes were witnessed such as internal and external migration (Dursun, 2003) Under these circumstances, the military intervention of March 12, 1971 was made, and the parliament was suspended relatively. The basic law was passed by the governments which were established after the military intervention. In general, it is not difficult to sense classical constitutive ideology "settings" in both the basic law and the basic principles. I can be suggested that the classical positivist and classical Kemalist line is dominant in the basic principles.

The second sub-aim of the study is to determine which principles undergo what changes in which periods. In this context, it is observed that the basic principles were changed three times in 1983, 1997 and 2009. Accordingly, the findings of the research based on this subpurpose were examined under three subtitles as Changes in 1983, 1997 and 2009. The Changes First Made in 1983 are given in Table 1.

Table 1

The Changes Made in 1983

\begin{tabular}{|c|c|c|}
\hline & 1973 & 1983 \\
\hline $\begin{array}{l}\text { Atatürk } \\
\text { Revolutions and } \\
\text { Turkish/ Atatürk } \\
\text { Nationalism }\end{array}$ & $\begin{array}{l}\text { Based on Atatürk Revolutions and } \\
\text { Turkish nationalism... At every } \\
\text { level of education of Turkish } \\
\text { language... ... enrichment of } \\
\text {....modern language of education and } \\
\text { science ... }\end{array}$ & $\begin{array}{l}\text { Ministry of National Education and Atatürk } \\
\text { Cultural Language and History Institution } \\
\text { take necessary actions to ensure...Basing on } \\
\text { Atatürk Revolutions and Atatürk nationalism... } \\
\text { Turkish Language at all levels of education... } \\
\text { modern language of education and science... }\end{array}$ \\
\hline $\begin{array}{l}\text { Democracy } \\
\text { Education }\end{array}$ & $\begin{array}{l}\text { Democracy awareness, social } \\
\text { responsibility, respect for spiritual } \\
\text { values, political views against } \\
\text { Turkish nationalism, which is } \\
\text { expressed in the Constitution... }\end{array}$ & $\begin{array}{l}\text { Democracy awareness, social responsibility, } \\
\text { respect for spiritual values, political views } \\
\text { against Atatürk nationalism, which is } \\
\text { expressed in the Constitution... }\end{array}$ \\
\hline
\end{tabular}


An Evaluation on the Change of the Basic Principles of Turkish National Education in the Context of Sociopolitical Paradigms

$\begin{array}{lll}\text { Secularism } & \text {...Secularism is essential... Religious } & \ldots \text { Secularism is essential. Religious culture and } \\ & \text { education... is given upon request ... } & \text { moral knowledge ... are among the compulsory } \\ & \text { courses }\end{array}$

As can be seen in Table 1, the following differences are observed between the first text in 1973 and the regulations made in 1983: First of all, the changes are in the dimensions of nationalism, democracy and secularism. In other words, instead of the concept of "nationalism" in the text of 1973, the concept of "Atatürk nationalism" was used. It can be said that the aforesaid amendment was a reaction to the nationalist socialist camp which was a fact for youth and public before 1980. As a matter of fact, hard struggles and conflicts between the nationalist front governments and the left, socialist and revolutionary political lines in general were intense in the mentioned period. The discussions on "nationalism" and "patriotism" caused severe political polarization in the society. The main reason for including and trying to impose the "Atatürk nationalism" approach is the tendency to be "reconciling". Assigning the preservation mission about language and culture to the Ministry of National Education (MNE) and Atatürk Cultural Language and History Institution (ACLHI) is also the outcome of the political conflict. The criticism of the Turkish Language Association (TLA) and Turkish Historical Society (THS), which were relatively more autonomous regarding the use of language and cultural preferences before the military government was intense (Aydın and Taşkın, 2016). This can be interpreted as the result of attitude of military government, differentiation of administration through new higher organizations and the efforts to find a middle ground for stability. In addition, it can be argued that education was ascribed the missions of integration, protection and social auditing. ng function and social control task are loaded into education. This can be interpreted as a "pedernalist", or "fatherly" (Yayla, 2019) with its definition in political science. Especially the Atatürk Revolutions and the Turkish / Atatürk Nationalism dimension were criticized frequently by different political views and were found as "doctrinarian". It was frequently stated that people who adopted different views besides Kemalism might also have patriotic feelings (Ar1, 2008).

The change within the context of secularism is as follows: Secularism was taken as the "basis" in both periods. On the other hand, in the 1983 amendment, the religious culture and moral education became the compulsory lesson in primary schools, high schools and equivalent schools. This is highly criticized by different political lines (Coşkun, 2012) 
Analyzing the reasons of the amendments, it is observed that the religion and ethnic origin conflict tendency are the main concerns. "Conflicts can be prevented if individuals are trained in a single point of view" is the logical basis for the amendments. It is possible to see this basic concept in the whole of the 12 September military administration. In fact, in this period, it is the central tendency to impose a "synthesist, intermediate but monistic" approach as an anti-thesis between conflicting approaches. However, the subject of "secularism", particularly compulsory religion lessons, has been constantly discussed since then. Especially citizens of different religions and different faith groups within the Islamic religion have constantly opposed the concept of "compulsory religion lesson.

The effects of the social, economic and political situation before the military intervention on 12 September 1980 in the amendments made in 1983 are obvious. Namely, in the aforesaid period, weak governments, different social segments which were polarized based on social, class, belief, and political context were experiencing an escalating internal conflict process, and the politics in the parliament was blocked, and the political authorities did not have the foresight to stop the anarchy and terrorist events (Ruscuklu, 2008). Parliament was not able to elect the president; it was stated by the highest level officials that social awakening was faster than economic development (Hür, 2015; İnce, 2017). In fact, this confirms that the amendments focused on ideology and religious education.

The basic principles after the amendments which were made in 1997, is given in Table 2.

Table 2

The Amendment Made in 1997

1973

1997

$\begin{array}{ll}\begin{array}{l}\text {... are directed considering their interest } \\ \text { and ability... }\end{array} & \begin{array}{l}\text {.. They are directed and raised according to their } \\ \text { interest and ability. To serve this purpose, preparatory } \\ \text { classes can be opened in secondary education } \\ \text { institutions in accordance with the objectives of the } \\ \text { e. is arranged in such a way as to realize }\end{array} \\ \begin{array}{l}\text { t.. educational guidance services and } \\ \text { objective assessment and evaluation } \\ \text { methods are used }\end{array} & \begin{array}{l}\text {... objective assessment and evaluation methods are } \\ \text { utilized... }\end{array}\end{array}$


The amendment made in 1997 on the basic principles of national education is the article about educational guidance. In this dimension, the regulations in 1973 and 1997 were based on the objective understanding of assessment and evaluation, and directing individuals to various programs or schools in the context of and in line with their interests and abilities throughout their educational life. However, in 1997, it was decided to add "preparatory classes" to the same article. This can be interpreted as an improvement attempt against criticism and some problems which occurred in practice. Moreover, it is open to some comments as a problem related to the secularism.

The amendment can be interpreted as the outcome of the unitary understanding of secularism, which has been formed since the Early Republic and aimed at social control of religion. In this period, information and communication technologies developed rapidly; It was a period when examples of real socialism such as Russia and Eastern Europe were destroyed. It is a period when political Islam gained power with such examples as Afghanistan and Iran. In general, the period between 1930s and 2000s is the time when the views against the basic qualities of the Early Republic began to gain strength with the constitutional amendments of 1946, 1961, 1982 and some other changes in the 1990s (Bölügiray, 1999). The opposing view, on the other hand, interprets the opposing actions which were directed towards the existing power as opposition to the guardianship and struggle for normalization (Erdoğan, 2000). Although it is another topic of discussion to view the educational guidance as correct or not in terms of "pedagogy" and "positivist" philosophy, the consideration that the educational guidance is basically about "imam hatip high schools" has always been relevant.

The basic principles after the amendments which were made in 2009 , is given in Table 3 . 
Table 3

The Amendment Made in 2009

1973

2009

\begin{tabular}{lll}
\hline & & $\begin{array}{l}\text { In the same site... education campuses can be established } \\
\text { and the campus management can be organized to meet }\end{array}$ \\
their common needs... & .. Cooperation between school \\
& and family is ensured... & . School-family unions are established. School-family \\
& school-family associations can & associations can... accept donations in cash and kind, \\
& accept all kinds of aid and & make financial contributions... organize events and \\
\end{tabular}

Analyzing Table 3, it can be observed that the principle which was formed as "Cooperation of the Family with the School" was changed as "Education Campuses and / Cooperation of the Family with the School" with the amendments made in the basic principles in 2009. Deviation from traditional school-family cooperation in schools is clearly observed in this amendment. Although traditional school-family cooperation is relatively maintained, a tendency for associations to work effectively and efficiently is observed. It can be interpreted as a synthesis of market-based operation and social traditions that school-family unions can organize social and cultural activities and campaigns in order to gain financial contribution and can accept donations in-kind and cash. Adding establishment of education campus managements to this principle can be interpreted as a more holistic and "commercial" approach to schools. This can be viewed as a tendency towards the "entrepreneur school" approach which is increasingly decentralized and creates its own economic power instead of the school which is funded by the "state budget" (Erdoğan, 2017). This can also be interpreted as a reflection of free market economy, competition and entrepreneurship (Doğan, 2004), which are the basic demands and expectations of globalization.

The situation that occurred in the aforementioned period can be summarized as follows: Relatively civil governments come to power after military governments which were formed due to a socially turbulent period. After the coalitions, the long-term single party is in power. However, the single party period suggests dissenting theses on the issues of "secularism, democracy, parliamentary system" which have been discussed continuously in previous 
years. Severe, serious criticism and reconstructivist conservative actions towards the traditional Republican structure formed since the Early Republic exist. Moreover, "national unity" encounters ethnic debate and conflict (Şahin, 2006). At this point, constitutional arrangements are made for the transition to the presidential system and for the union of powers. In a sense, it is a conflicting and debating period on the secularism and national unity which are among the traditions of the republic formed in eighty years.

\section{Discussion and Conclusion}

When looked at the effects of change in historical developmental process, these results can be concluded: Social change heavily effects secularism. Political change heavily affects the dimensions of nationalism, secularism, family and school cooperation. Also, the change in the economic dimension is effective on secularism and family-school cooperation. These facts can be seen at Figure 1: 


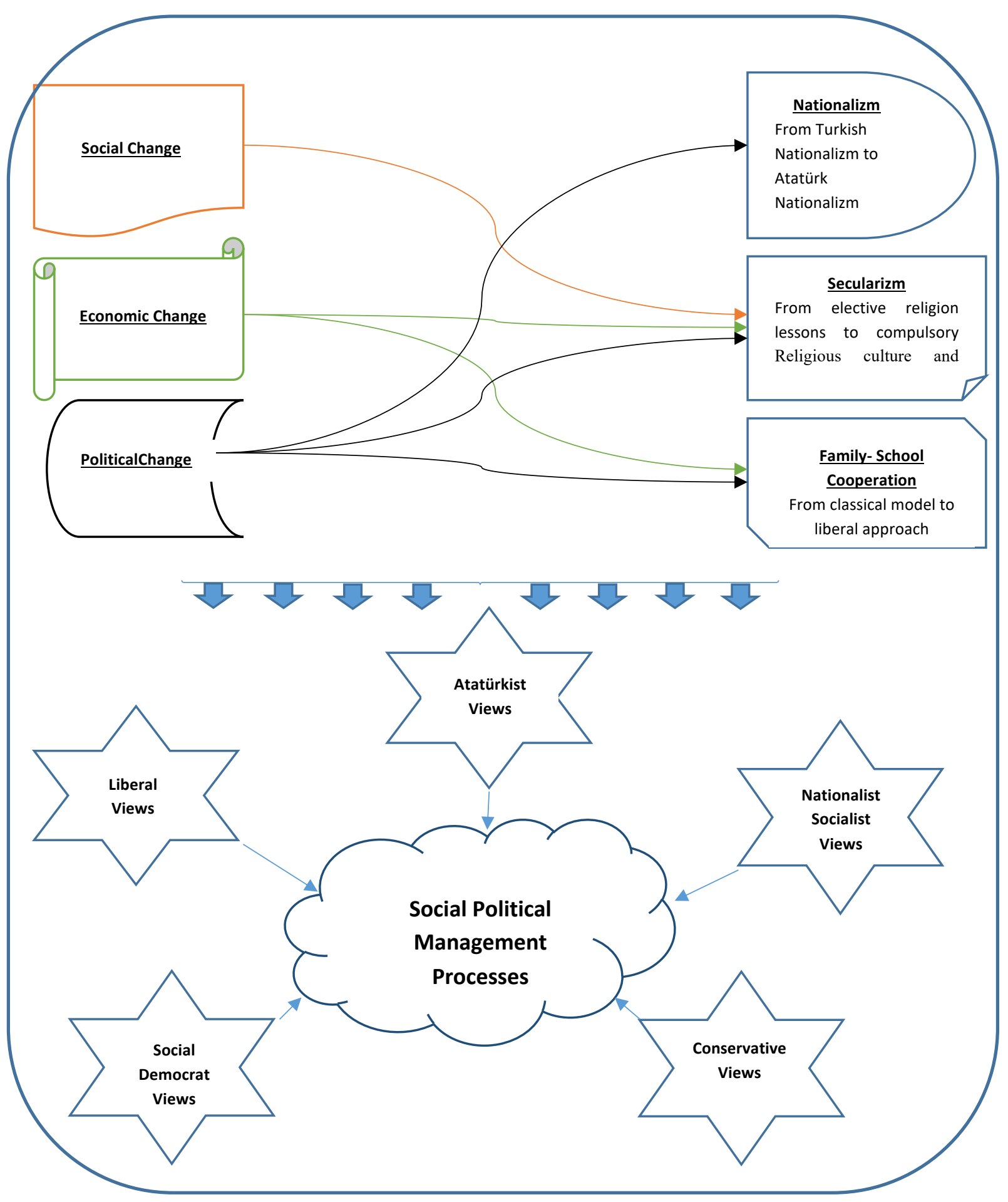

Figure 1. The Dimensions of change and effects of basic principles

The basic principles have been changed three times since its first entry into force. Turkey was in depressed and conflicting periods based on economic and socio-political problems when the basic principles were first promulgated in 1973 and then amended in 1983, 1997 and 2009. Each change was made in the periods in which Turkey was experiencing social, 
economic and political turbulent. This is a historical example in terms of explaining the relationship and interaction between politics and education. In a sense, whenever a political conflict occurs, it can be claimed that an arrangement in education according to the political course becomes a current issue. It is not a coincidence. The first two were the period of military intervention, and the 2009 amendment coincides with the post-2007 period, which was interpreted as the period of significant transformation of the first republic by new conservatives. In conclusion, amendments to the basic principles are made in the periods when Turkey experience social and political changes.

Another finding regarding the change of the basic principles is that changes are made in the "much debated" issues in social, economic and political contexts. Topics for which changes are made are Ataturk reforms and Turkish nationalism, secularism, educational guidance, education of democracy and the cooperation of the school and the family. These issues are generally discussed by the Turkish public and politics. These issues are also related to issues of globalization, democratization and privatization, which have been discussed extensively since the last quarter of the twentieth century.

Considering Atatürk nationalism among the topics discussed, the following points come to the forefront: In this context, approaches can be divided into two different groups. In general, in the context of "Atatürk nationalism", the conservative and political Islamist wing expresses harsh criticism. Liberal lines also join these criticisms at some points. For example, it is argued that the Kemalist ideology on which everyone agrees do not really exist and it is ideological to include it in such official documents as the basic principles and the it is not democratic (Çaha, 2013). While similar criticisms are sometimes directed by socialist groups, some of the socialist groups emphasize that Atatürk is an "important" revolutionist.

Secularism is another one of the basic principles which are subject to change and discussed intensively. Discussions on secularism can be examined in two different groups. The first group is generally a conservative and nationalist socialist group, and supports the necessity of compulsory religious classes and opposes the amendment of this article. In contrast, socialist movements, liberal views, social democrat and Kemalist view groups are against the compulsory religious classes. The common ground of these views is that, according to secularism, the state should be equidistant to all religious and belief groups. It is against 
secularism to teach a religious lesson in which only Islamic religion and even Sunni belief is taught.

The change in educational guidance was made in 1997. The real debate on this issue is the question of how and to which school the primary and post-secondary students will be directed. The issue of educational guidance has emerged from debates on pedagogical guidance and gained an ideological form in the progress of time and been discussed in the context of imam hatip high schools. The real problem, however, is a "pedagogical" problem about how to guide students about their careers.

\section{The criticism towards the principle regarding the dimension of democracy education is} the lack of tolerance of political views contrary to Turkish nationalism, which is enshrined in the constitution, and which is expressed as Atatürk nationalism in the next regulation. However, the political system should be open to all views based on general understanding of democracy, (Erdoğan, 2000). The shift from Turkish nationalism to Atatürk nationalism can be interpreted as a reaction to the events before September 1980. Indeed, the same attitude was reflected in the 1982 Constitution Act and the constitution evolved into a strict, regulatory (casuistic) form (Teziç, 2017). However, it is widely discussed that a significant erosion and breakdown has been observed starting from 2010 in the principles which bear the traces of the positivist and progressive philosophies such as Atatürk nationalism, mixed education, scientific and secularism (Çeltikçi, 2014).

It can be suggested that an addition to and renewal with Education Campuses and / School and Family Cooperation within the context of Education Campuses. The change can be interpreted in two ways considering the understanding of Education Campuses. The first group interprets the aforesaid view change as a preparation for privatization. According to this view, the withdrawal of the state from all public areas step by step after 1980s is seen as a step towards privatization in the field of education. As a matter of fact, news about the transfer of new campus areas, school buildings, gardens and lands in the city center to the private sector is frequently mentioned. The second opposing group is indecisive about this situation. If it is implemented well, the practice of education campuses will give desired results (Erdoğan, 2017). 
In conclusion, the following views come to the fore as a result: The change in basic principles mainly correspond to the social, economic and political turbulent periods of the country. Views on change differ according to philosophical view, political preferences and beliefs. The academic and scientific consideration of educational problems remains weak compared to the philosophical, political and belief-based interpretations. In Turkish society, it is the increasing tendency to consider problems according to philosophical, belief, ethnic and political views.

\section{Suggestions}

- The basic principles which are subject matter of the research can be studied quantitatively and qualitatively in order to determine the views of different human resources such as teachers, administrators, unionists, students and parents who are directly affected by education or directly affect education.

- Oral education history researches can be conducted on the reasons for the change in the basic principles consulting the opinions of the experts who lived at that time.

- Based on the fact that the basic principles have been changed, qualitative research based on receiving opinion can be conducted to reveal how the contents of the amended articles are interpreted by academics, teachers and parents.

- This study is a national level assessment. Thus, studies on comparing the basic laws or basic principles of education in other countries can be conducted.

\section{Statements of Ethics and Conflict of Interest}

"I, as the Corresponding Author, declare and undertake that in the study titled as "An Evaluation on the Change of the Basic Principles of Turkish National Education in the Context of Sociopolitical Paradigms", scientific, ethical and citation rules were followed; Turkish Online Journal of Qualitative Inquiry Journal Editorial Board has no responsibility 
for all ethical violations to be encountered, that all responsibility belongs to the author/s and that this study has not been sent to any other academic publication platform for evaluation."

\section{References}

Açıkgöz, İ. (2015). Okullar açılırken Türk milli eğitim sistemine bakış. [An outlook on the Turkish national education system as schools open] Evrensel. Retrieved from: https://www.evrensel.net/yazi/74948/okullar-acilirken-turk-milli-egitim-sisteminebakis

Akın U. ve Arslan, G. (2014). İdeoloji ve eğitim: Devlet-eğitim ilişkisine farklı bir bakış [Ideology and education: A different perspective on the state-education relationship]. Trakya Üniversitesi Ĕ̈itim Fakültesi Dergisi, 4 (1), 81-90.

Akıntürk, T. (2008). Hukuka giriş [Introduction to law] (9. Baskı) Eskişehir: Anadolu Üniversitesi Açık Öğretim Fakültesi Yayını.

Akyüz, Y. (2010). Türk eğitim tarihi M.Ö. 1000- M.S. 2010 [Turkish education history 1000 B.C. - 2010 A.D.] .(17. Baskı). Ankara: Pegem Akademi.

Arı, A. S. (2008, 3 Eylül). Milli eğitimin amaçlarındaki çelişkiler [Contradictions in the goals of national education] [Blog yazisı]. Retrieved from: http://asuatari.blogspot.com/2008/09/milli-eitimin-amalarndaki-elikiler_03.html

Aybek, Ş. (2015). Atatürk, CHP ve eğitim [Atatürk, Republican People's Party, and education]. Ankara: Son Çağ Yayınları.

Aydın, S ve Taşın, Y. (2016). 1960'dan günümüze Türkiye tarihi [Turkey's history from 1960 to present day]. (4. Baskı). İstanbul: İletişim Yayınları.

Aytaç, K. (2001). Atatürk'ün Eğitim görüşleri [Atatürk’s view on education] Atatürkçülük II. Kitap Atatürk ve Atatürkçülüğe Illişkin Makaleler içinde (s. 103-113). İstanbul Milli Eğitim Basımevi.

Baloğlu, Z. (1990).Türkiye'de eğitim sorunlar ve değişime yapısal uyum önerileri [Education problems in Turkey and structural adaptation suggestions to change]. İstanbul: TÜSİAD Yayını.

Başdemir, H. Y. (2015). Yeni Türkiye'ye yeni eğitim anlayışı [ New education conception for new Turkey]. Star. Retrieved from: http://www.star.com.tr/ acik gorus/yeniturkiyeye-yeni-egitim-anlayisi-haber-989717/ 
Batur, O. (2016). Milliyetçilik Kuramları - 1 [Theories of nationalism-1], Ernest Gellner, Uluslar ve Ulusçuluk. [Blog yazısı]. Retrieved from: https://medium. com/@oguzkhanbatyr/milliyet.

Bölügiray, N. (1999). 28 Şubat süreci [The February 28 process]. İstanbul: Tekin Yayınevi.

Braun, V. \& Clarke, V. (2006). Using thematic analysis in psychology. Qualitative Research in Psychology, 3 (2), 77-101.

Coşkun, U. (2012, 27 Ağustos). "Yeni dönemde milli eğitimin temel ilkeleri nasıl olmalı? [How should the basic principles of national education be in the new period?] . Yeni Şafak. Retrieved from: http://www.yenisafak.com/yerel/yeni-donemde-milli-egitimintemel-ilkeleri-nasil-olmali

Çaha, Ö. (2013). Sivil Toplum ve Özgürlükler Bağlamında Modern Dünyada Eğitim Sorunu [Education Issue in the Modern World in the Context of Civil Society and Freedoms]. [Blog yazıs1]. Erişim tarihi: http://www.liberal.org.tr/sayfa/sivil-toplum-ve-ozgurlukbaglaminda- modern-dunyada-egitim-sorunu-omercaha,209.php.

Çeltikçi, E. (2014, 24 Kasım). Milli eğitimin 14 ilkesi kırıldı [14 principles of national education are broken]. T24. Retrieved from: http://t24.com.tr/haber/milli-egitimin-14ilkesi-kirildi,278167

Çiftyürek, S. (2013, 5 Ocak). Türban, zorunlu din dersi ve anadilde eğitim [Turban, compulsory religion lesson and education in mother tongue] [Blog yazısı]. Retrieved from: http://www.sinanciftyurek.com/turban-zorunlu-din-dersi-ana-dilde-egitim/

Doğan, İ. (2004). Toplum ve eğitim. Ankara: Pegem A Yayıncılık.

Dursun, D. (2003). 12 Mart darbesi hatıralar gözlemler düşünceler[12 March military intervention, memories, observations and thoughts]. İstanbul: Şehir Yayınları.

Ekinci, T. Z. (2014, 3 Ekim). HDP'nin önündeki sorunların kaynağı [Source of the problems before People's Democratic Party] [Blog yazisi]. Retrieved from: https://bianet.org/bianet/bianet/\%20158912-hdp-nin-asmasi-gereken-onyargilar

Ekiz, D. (2009). Bilimsel araştırma yöntemleri[Scientific research method]. (Geliştirilmiş 2. Bask1). Ankara: Anı Yayıncılık.

Erdoğan, E. (2019, 8 Haziran). Eğitim kampüsü liselerde kaliteyi yükseltir mi? [Does education campus improve the quality at high schools?] [Blog yazıs1]. Retrieved from: https://ozelogretim.org.tr/2019/06/08/egitim-kampusu-projesi-kaliteyi-yukseltir-mi/

Erdoğan, M. (2000). 28 Şubat süreci. İstanbul: Yeni Türkiye Yayınları. 
Gezgin, U. B. (2017, 1 Ekim). Eğitimin okulların dışına çıkması: İyi mi kötü mü? [Education out of school, good or bad?] . Evrensel. Retrieved from: https://www. evrensel .net/haber/333877/egitimin-okullarin-disina-cikmasi-iyi-mi-kotu-mu

Glesne, C. (2012). Nitel araştırmaya giriş [Introduction to qualitative research]. A. Ersoy ve P. Yalçınoğlu (Çev.). Ankara: Anı Yayıncılık.

Hanioğlu, Ş. (2017, 5 Şubat). Kemalizm ve demokrasi [Kemalism and democracy]. Sabah. Retrieved from: https://www.sabah.com.tr/yazarlar/hanioglu/2017/02/05/kemalizmve-demokrasi

Hür, A. (2015). Darbeli ve çatışmall ylllar[Times of military interventions and conflicts]. İstanbul: Profilo Yayınları.

İçer, M. M. (1997). Türk milli ĕgitim sisteminin genel amaçlart ve temel ilkelerinin degerlendirmesi[Evaluation of the general objectives and basic principles of the Turkish national education system]. Yayınlanmamış Yüksek Lisans Tezi. Malatya: İnönü Üniversitesi, Sosyal Bilimler Enstitüsü.

İlkaya, M. A. (2014). Eğitim Reformu, firsatlar engeller [Education reform, opportunities and obstacles]. [Blog yazısı]. Retrieved from: http://www.liberal.org.tr/sayfa/egitimreformu-firsatlar-engeller-mehmetalimilkaya, 585. php.

İnal, K. (2008). Ídeoloji ve eğitim [Ideology and education]. Ankara: Kalkedon Yayınc1lık.

İnce, M. (2017). Darbeler ve demokrasi öncesi sonrası ve sonuçlarlyla 27 Mayıs-12 Mart-12 Eylül[Military interventions and 27 May-12 March-12 September with post-pre democracy outcomes]. İstanbul: Boyut.

Kenar, C. (2015, 16 Mart). Türkiye'nin asıl endişeleri muhafazakârlar [Real anxious people of Turkey: conservatives]. Türkiye Gazetesi. Erişim adresi: http://www.turkiyegazetesi. com.tr/gundem/246614.aspx

Kışlalı, A. T. (2010). Siyasal sistemler-siyasal çatışma ve uzlaşma[Political systemspolitical conflict and reconciliation. (8. Bask1). Ankara: İmge Kitabevi.

Kışlalı, A. T. (2016). Siyaset bilimi [Politics]. (17. Bask1). Ankara: İmge Kitabevi.

Kızılok, U. (2013). AKP ve Anadilde Eğitim [Justice and Development Party and education in mother tongue]. [Blog yazıs1]. Retrieved from: http://marksist.net/utku-kizilok/akpve-anadilde-egitim.html. 
Kirk, R. (1993). Muhafazakârlı̆̆ın 10 Prensibi [ 10 fundamentals of conservatism] (Çev. Okan Aslan). [Blog yazisı]. Retrieved from: http://www.muhafazakar. com/muhafazakarligin-10-prensibi.

Kongar, E. (2016). Atatürk üzerine[On Atatürk]. (Genişletilmiş Yeni Basım). İstanbul: Remzi Kitabevi.

Macionis, J. J. (2013). Sociology. (13 Bask1). New York: Pearson.

McMillan, J. H. (2004). Educationalresearch: Fundamentals for the consumer. (Fourth Ed.). Boston: Pearson.

Özçelik, M. (2016). Siyasi bir ideoloji olarak muhafazakârlık ve Türkiye'de muhafazakârdemokrat siyasal kimliğiyle AK Parti [Conservatism as a political ideaology and Justice and Development Party with conservative-democrat identity in Turkey]. Yayımlanmamış Yüksek Lisans Tezi. Konya: Necmettin Erbakan Üniversitesi, Sosyal Bilimler Enstitüsü.

Öztürk, E. (2016). Millî Türk talebe birliğinde değişen milliyetçilik anlayışı ve antikomünizm [ Changing nationalism concept of national Turkish student association and anti-communism] (1965-1971). Süleyman Demirel Üniversitesi Sosyal Bilimler Enstitüsü Dergisi, (25), 103-126. Retrieved from: http://dergipark.org.tr/tr/pub/sbe/issue/27211/292177

Ruscuklu, B. (2008).Demokrat Parti'den 12 Eylül'e [ From Democrat Party to 12 September]. İstanbul: Alfa Yayınları.

Sarıca, M. (2017). 100 soruda siyasi düşünce tarihi [History of political thought in 100 questions] İstanbul: Milenyum Yayınları.

Şahin, M. (2006). MGK 28 Şubat öncesi ve sonrasi[National Security Council before and after 28 February]. İstanbul: Pelikan Yayınları.

Tezcan, M. (1993). Ĕ̆itim sosyolojisinde çă̆daş kuramlar ve Türkiye[Contemporary theories in education sociology and Turkey] . Ankara: Ankara Üniversitesi Yayını.

Tezcan, M. (2011). Atatürk ve eğitim bilimleri[Atatürk and educational sciences]. (3. bask1). Ankara: Anı Yayıncilık.

Teziç, E. (2017). Anayasa hukuku[Constitutional law]. (21. Baskı). İstanbul: Beta Yayınları.

Toprakçı, E. (2011). Atatürk'ün eğitim felsefesi yazdıkları söyledikleri 1şığında[Atatürk’s education philosophy in the light of his writings and speech]. E-Uluslararası Ĕgitim 
Araştırmalarl Dergisi, 2 (4), 1-27. Retrieved from: http:// dergipark.gov.tr /download/article-file/89747

Yayla, A. (2019). Siyasi düşünce sözlüğü [Dictionary of political thoughts]. (7. Bask1). Ankara: Adres Yayınları. 